\title{
Rethinking the Man in Black: The Unconscious as a Mechanism in El cuarto de atrás
}

\section{Elizabeth SOTELO' ${ }^{10}$}

${ }^{1}$ M.A., University of Oregon, Department of Romance Languages, Eugene, United States

ORCID: E.S. 0000-0001-7685-3534

\section{Corresponding author:}

Elizabeth SOTELO,

University of Oregon, Department of Romance Languages, 102 Friendly Hall, 1233 University of Oregon, Eugene, OR 97403-1233

E-mail: esotelo@uoregon.edu

\section{Submitted: 30.07 .2019}

Accepted: 06.10.2019

Citation: Sotelo, E. (2019). Rethinking the man in black: the unconscious as a mechanism in El cuarto de atrás. Litera, 29(2), 207-217.

https://doi.org/10.26650/LITERA2019-0033

\begin{abstract}
This study offers new thoughts on the ambiguous presence of the man in black in the novel El cuarto de atrás (1978), by the Spanish writer Carmen Martín Gaite, Throughout the text, we have the uncertainty of not knowing if the man in black really exists, if he is a mental creation of the protagonist C., or if, indeed, any of the dialogue is trustworthy. Martín Gaite employs the enigmatic presence of the man in black to produce uncertainty throughout the plot. Based on this ambiguity, we seek to provide a new rethinking of the representation of the man in black. It is established that the man is a mechanism of the protagonist $C$., to guide her in her search to overcome her fears rooted in her turbulent past. Following the theoretical concept of Sigmund Freud, we seek to argue that, within an abstract dream, the unconscious of the protagonist is depicted in the shape of the man in black. It is only through the personification of her unconscious how C. examines her past, explores her present, and exhibits social and political criticism. She defeats her fears, reconstructs herself, and obtains a narrative for the book she is writing.
\end{abstract}

Keywords: Interlocutor, Unconscious, Spanish novel, Twentieth century, Freud 
"...clama por ser ella misma -lo que quiera que esto sea-..."

"... pleads to be -anything it might be-..." (Carbayo, 1998, p. 120)

\section{Introduction}

In El cuarto de atrás (1978), written by Spanish author Carmen Martín Gaite, the plot of the novel is developed from the conversation between the protagonist, $C$., and the man in black - Alejandro. The man is the interlocutor who questions while $C$. responds. Their dialogue allows the protagonist to overcome her fears rooted in the past. Her fears include the fear of uncertainty, the fear of fantasy, the fear of love, the fear of remembering the past, and the fear of understanding her past. $C$. has reached an age where solitude has been her only companion. Until her dialogue with Alejandro, she had not found an individual to help her go into her past and stay close while she sought to overcome her fears. However, both the appearance and disappearance of the man in black are ambiguous. We are introduced to the man when $C$. receives a call from him, following an interview which she cannot remember. The ambiguity around him continues as, near the end, $C$. awakens from her sleep and he has vanished. In addition, her sleeping pills add more incertitude to the line between reality and hallucination. Due to these circumstances, we seek to argue that the man in black is an internal construction. The theory of Sigmund Freud regarding the existence and representation of the unconscious is the foundation of the present study. The article demonstrates that $C$. manages to detach herself, from her conscious and her unconscious, by projecting her unconscious into the mysterious figure of the man in black. Based on all this, $C$. is capable of reconstructing herself using the man in black as a guide, as a reference for the present, and as a mechanism for criticism.

\section{The man in black}

The similarity between the devil and the man in black has been studied extensively. This connection is based on the photo of the devil, in the book Conferencia de Lutero con el diablo (Luther's conference with the devil), due to it being physically black (Martín Gaite, 2003, p.18). C. explicitly declares, "...esta leyenda me ayuda a escapar del sortilegio que la habitación pintada empezaba a ejercer sobre 
mí, me ha parecido que cobraba relieve y profundidad, que me estaba metiendo en ella..." ("... this legend helps me to escape the spell that the painted room began to exercise on me, it seemed to me that it gained relief and depth, that I was getting into it ...") (Martín Gaite, 2003, p. 18-19). The legend of the devil begins to create an escape in the mind of $\mathrm{C}$. However, the uncertainty of not knowing assuredly who the man is or what he represents, allows us to deconstruct this character. The connection linking Alejandro and devil is not refused, but the probability that he represents a part of $C$. must not also be rejected.

The man, along with the plot, allows a different approach to understanding him and his relationship with $C$. The protagonist goes on to comment, "...las estrellas se precipitan y aún tengo tiempo de decir «quiero verte, quiero verte», con los ojos cerrados; no sé a quién se lo digo" ("... the stars rush and I still have time to say «I want to see you, I want to see you», with my eyes closed; I do not know who I say it to") (Martín Gaite, 2003, p. 25). It is suggested that C. was thinking about someone or something that she wanted to see, but the enigmatic stars, that possibly represented the effects of the sleeping pills, created more confusion. However, in the quiero verte, quiero verte there is an understanding that $\mathrm{C}$. is aware of the existence of the interlocutor, in the real present, but she has not been able to see him. After the stars, the man in black is introduced in a phone call. The line between reality and imaginary is obscure. She enters into a dream where those that exist are her conscious, her subconscious, and her unconscious. She needs someone or something that knows her, to help her end her solitude, and allow her to dialogue (Guerrero, 1992, p. 331). Researcher Mario Santana explains the role of the interlocutor should be to ask and refrain from questioning although he knows her (Santana, 2011, p. 103). Given this context, the man in black can be considered as a projection of $C$. since he is familiar with her past. He represents the unconscious that knows her and that hopes she will dismantle her past. Furthermore, researcher Adrián M. García affirms, "In fact, he is somewhat feminized, showing interest in things such as C.'s techniques for curling her hair" (Garcia, 2000, p. 48). The feminization of the man confirms that he is a part of $C$. Regarding his connection with the devil, considering it was the image she saw before falling asleep due to the pills, the devil became the abstract image that her brain used to project her unconscious. The conscious of $C$. contains her fears while her unconscious holds repressed memories. To be familiar with $C$., the man needed to be aware of those suppressed memories, therefore, he could only be a depiction of her mind. 


\section{The man as a guide}

C. can control who the interlocutor in her dream is. Only her unconscious is the ideal interlocutor since it knows $C$. and understands the process by which she might free herself. The man, together with $C$., allow the existence of " ... many silences in dialogue and interior monologue, like silences in music, amplify surrounding sounds and words, and enable the characters and reader to fully experience the present and to contemplate the past, present, and future" (García, 2000, p. 52). Silence is the solution to allow the protagonist to process her memories as she answers the interrogation of Alejandro. The silence of the man, during the mindscapes of $\mathrm{C}$., has a resonance in the characteristics of an unconscious. Additionally, when interrogating her, Alejandro comprehends precisely what he should ask to assist $C$. and allow her to efficiently reproduce her suppressed memories. This can be observed in a conversation between the two:

- ¿Hace mucho que vive en esta casa?

-Desde el año cincuenta y tres.

Suspiro. He vuelto a coger el hilo, como siempre que me acuerdo de una fecha. Las fechas son los hitos de la rutina. (Martín Gaite, 44) (Have you lived in this house for a long time?

-Since 1953.

Sigh. I have picked up the thread again, as always when I remember a date. Dates are the milestones of the routine). (Martín Gaite, 2003, p. 44)

The association linking home and date are fundamental to obtain the reproduction of past memory and to forge a path to scrutinize beyond that past. Alejandro, the man in black, wants $C$. to remember her childhood. Her infancy was a period when her home and the date existed in a different context. The specific questions demonstrate that he knows $C$. beyond her current present and her near past.

The particular questioning, about the house, exemplifies his connection to $C_{\text {.; }}$ he is her unconscious in this ambiguous dream. The ambiguity can be explained through the following statement, "Unconscious processes can only be observed by us under the conditions of dreaming and of neurosis..." (Freud, 1963, p. 135). The man, in the fiction 
novel, shelters the essence of $C_{\text {., }}$ all her fears and memories. She is able to see him and speak with him due to her sleeping state. The dream is the path needed to observe her unconscious processes in the form of a man. It is solely in the dream, where she is capable of building a space where she can free himself from her fears, and remember her genuine past. Researcher Olga Buczek indicates, “...el interlocutor perfecto sólo está en nuestra mente como producto de la imaginación. De esta manera, el que escribe, se defiende de la incomunicación que sufre en la vida cotidiana" (" ... the perfect interlocutor is only in our mind as a product of the imagination. In this way, he who writes, defends himself from the lack of communication he suffers in everyday life") (Buczek, 2009, p. 10). The protagonist requires someone who is built based on her desire for the ideal interlocutor. She understood that solely in her imagination could she possibly conceive it. This would further strengthen the moment where she is falling asleep and expresses, I want to see you. Then, she subsequently manages to see him. The man does not sufficiently identify himself and the narrator also shows no interest in identifying who he really is (Buczek, 2009, p. 13). She gives him complete confidence and allows him to guide her during her mindscapes because internally she is aware that this man is her own creation. The man in black is the ideal guide for he has previously endured the process $C$. needs to revisit.

\section{The man as a reference for the present}

There is a probability that by heading into the past, a person can get lost among their memories. Freud states that "Research has afforded irrefutable proof that mental activity is bound up with the function of the brain as with that of no other organ" (Freud, 1963, p. 124). There is the risk of becoming lost between sleep, memories, and life. It is beyond control to follow a complicated pattern, between past and present, while sleeping. This explains the necessity for an interlocutor who not only guides her but is also present with her as she dwells on her memories. This is observed in a passage of the childhood of $C_{\text {., }}$ in the circus, where she mentions:

...y yo quieta allí, entre el barullo, mirando fascinada los carteles donde se anunciaba lo que dentro de poco iba a ver; algo de temor sí, porque podían mirarme los leones o caerse el trapecista de lo más alto, pero también avidez y audacia y sobre todo, un sacarle gusto a aquella espera, vivirla a sabiendas de que lo mejor está siempre en esperar, desde pequeña he creído eso, hasta hace poco. Daría lo que fuera por 
revivir aquella sensación... (Martín Gaite, 2003, p. 12-13)

(... and I stood there, among the noise, looking fascinated at the posters that announced what I was going to see shortly; some fear yes, because the lions could have seen me or the trapeze artist could have fallen from the highest, but also avidity and audacity and above all, to take pleasure in that wait, live it knowing that the best is always waiting, I believed that since I was little, until recently. I would give anything to revive that feeling ... (Martín Gaite,2003, p. 12-13)

In this memory, C. starts to remember the feelings she had had since her childhood, but had recently lost. In her memory, she can connect the past with the present and understand that, in her present, she no longer possesses her childhood belief. The presence of the man in black keeps her in the present and allows her to travel back and forth in time.

The present is the moment she is sharing with the man. The French philosopher Jean Paul Gustave Ricoeur further elaborates by commenting: : “...si el recuerdo es una imagen en este sentido, conlleva una dimensión posicional que lo relaciona, desde este punto de vista, con la percepción" ("... if a memory is an image in this sense, it implies a positional dimension that relates it, from this point of view, to perception") (Martìn Gaite, 2000, p. 71). C.'s belief was grounded in the image of circus workers. She no longer believes that waiting will lead to something better because, in her own life, she had waited and recurred to building her current interlocutor. She understands that she is no longer a child, nor is she dealing with workers in a circus. She is the first-person narrator in the novel and reveals that she is writing a different book that is not a memory book. The novel, El cuarto de atrás, allows the existence of the author Carmen Martín Gaite and the protagonist, in the first person singular of the plot, $C$. The author has introduced herself in the novel, $C$. is the personification of Carmen the author. This disorder has a resonance in the process of how she decided to overcome her fears, a method which is also disorganized. In this manner, C., together with the help of the man, can recover her memories in a disorderly way because only in disorder one can obtain the key to life-giving memories (Guerrero, 1992, p. 330). In this chaos, of memory and time, the interlocutor is able to keep her present. 


\section{The man as a mechanism for criticism}

C., aware of the presence of the man, has the complete confidence to risk entering her memories. Given that "The unconscious has the greater compass: the repressed is a part of the unconscious" (Freud, 1963, p. 116). Her deep memories can be revealed due to the working presence of her unconscious in the form of a man. She is not only able to reveal her past, but also to graft her own criticism. C. recounts ,'...ahora pienso que la muerte de Hitler aquel mes de julio pudo cambiar el rumbo de la historia, pero yo entonces aborrecía la historia y además no me la creía, nada de lo que venía en los libros de historia ni en los periódicos me lo creía, la culpa la tenían los que se lo creían..." ("... now I think the death of Hitler that July could have changed the course of history, but I then abhorred history and also did not believe it, I did not believe what came in the history books nor in the newspapers, it was the fault of those who believed them... ") (Martín Gaite, 2003, p. 50). The narrator, up to her present, distrusts history in its oral and textual forms. She understands that, until her present, the history of Spain had been twisted to hide events that could harm the government or entities. This explanation about history happens in the dialogue as she escapes into the past. She has understood that the book, she has to produce, must be genuine and to be able to achieve that, she must remember her memories repeatedly. In order not to trigger ambiguous mistakes or memories, her unconscious must be exposed. Freud states, "The processes of the Ucs...are subject to the pleasureprinciple; their fate depends only upon the degree of their strength and upon their conformity to regulation by pleasure and pain" (Freud, 1963, p. 135). Before the creation of the man, the state of solitude and fear $\mathrm{C}$. was enduring was disturbed when she wanted to create a book that was unique. Her present circumstances and the fear of her memories led her to find a solution to her state and her new writing. The more she merged in the past, the more it gave her comfort.

The figure of the man in black is her support in the book she is writing. She wants to overcome her fears by using the man as an aid mechanism, but also to help her write her book which will be based on her experience with him. The protagonist explains: "Yo es que la guerra y la posguerra las recuerdo siempre confundidas. Por eso me resulta difícil escribir el libro" ("War and the postwar period are always confusing for me. That is why I find it difficult to write the book") (Martín Gaite, 2003, p. 111). C. recognizes that the memories, from her past and her present, at times become unclear. It is essential that an individual subsists with an intermediary agency 
between the past and the present and that also plays the center of the history of her book. The dream, in addition to being the space where she frees herself from her fears, becomes the space that provides the idea of producing a book that mixes fantasy and reality. The image of a man being a mysterious character, to the reader, adds uncertainty to her novel. Together, with the man, she can risk revealing her confusion about war and the postwar period. Professor and researcher Mercedes Carbayo Abengózar comments that the narrator "...comenzará un viaje exploratorio en busca de respuestas a esas contradicciones y de una identidad que, lejos de definirla o encasillarla en algo fijo, la mantiene en proceso de cambio y revisión" ("... will begin an exploratory journey in search of answers to these contradictions and an identity that, far from defining her or classifying her into something fixed, keeps her in process of change and revision") (Abengòzar, 1998, p. 116). It is in the absence of a chronological order that $\mathrm{C}$. is allowed to rescue her memories. The memories, of her unconscious, are possible to understand, in the moment, without needing to place them in a timeline. If there had been a linear sequence, she could not have grafted her criticism, but only continued the sequence of her memories. The non-linear guide allowed her to fully explore her memories. Her analysis recovered memories in isolation which was only possible by the arrangement of pure memory through the images (Ricoeur, 2000, p. 75). Images like Hitler or the war are those which emerge as the focus of different memories. It is understood that memory is based on an image that must be discovered by C. Researcher David K. Herzberger explains, "Memory forgets, revises, and transforms, so that the past remains ever open to rewriting and reinterpreting in ways that defy the design of myth" (Herzberger, 1991, p. 42). Based on the image and the memory that the image produces in the mind of the narrator, she can reinterpret the events from her perspective. The images from her past allow her to remember due to their uniqueness. This exclusivity reinforces her desire to finish the production of her uncommon book.

C. manages to return to her past, recover her memories, and build them according to her present. The constant presence of the man reminds her that she must continue with the interview and therefore be able to return to her present. The narrator overcomes the fears she has housed until her present by remembering them and grafting criticism. She is able to build herself, but constantly with the presence of the man in black. It can then be established that $C$. uses the man in black as a mechanism. The logic of why it is a male figure instead of a female figure is ambiguous. Freud reveals that the repressed idea, in the unconscious, remains competent in action and 
maintains its cathexis (Freud, 1963, p. 125). The essence of this memory or idea might have a connection with the maleness projected in the unconscious.

The dialogue with the man in black exists solely because C. allows him to appear in her dream. The credibility of the answers of $C$. is explained by Ricoeur, "Entonces sentimos y sabemos que algo sucedió, que algo tuvo lugar, que nos implicó como agentes, como pacientes, como testigos. Llamemos fidelidad a esta exigencia de verdad" ("Then we feel and know that something happened, that something happened, that involved us as agents, as patients, as witnesses. Let us call this truth requirement, faithfulness") (790). C. must be credible with her answers because, as the author she is, she is being interviewed. She must respond to what she is being asked to answer. Nonetheless, beyond the fidelity of the facts required by the interlocutor and us as readers, C. has been seeking, for her benefit, to recreate the facts. She does not necessarily let the man know what she is reviving. When evoking the frightful life of war and post-war, C. states, "Pero este hombre no se merece respuestas tópicas" ("But this man does not deserve topical answers" (Martín Gaite, 2003, p. 63). Finally, she ends up recounting that she remembered her childhood as a happy period based on the simple facts (Martín Gaite, 2003, p. 63). She is determined to use the man as an aid and as a tool, therefore, she limits the amount of information she is providing to him. The question lies in knowing why she limits her thoughts to the man if she knew he was her unconscious and therefore knows everything. In order to build herself as a person, C. has understood that her memories no longer belong to him, but to herself and where she wishes to keep them. In this way, C. removes the agency of the man from knowing everything so that she can recreate herself based on what she remembers and how she remembers.

The man was only a tool C. needed to help her and thus, he received her unconscious. In her book The Search for Interlocutor, Martín Gaite refers to the need to have an interlocutor who is "...con el deseo de romper la soledad: me refiero a la búsqueda de una destinatario para nuestras narraciones" ("....with the desire to break loneliness: I mean the search for a recipient for our narratives") (Martín Gaite, 2003, p. 25). Alejandro is the recipient she needs to guide her in order to travel to the past through her answers. However, after she has been able to recover the memories, she no longer needs Alejandro and falls asleep - which could also mean the effect of the sleeping pills. After getting up, and the effect of the sleeping pills have faded, Alejandro does not exist anymore. He has disappeared - or he has been withdrawn by the narrator. 


\section{The maleness of Alejandro}

While C. sought to overcome her fears, she created a male interlocutor to use him for her benefit. As she advances into her memories, she recalls, "La retórica de la posguerra se aplicaba a desprestigiar los conatos de feminismo que tomaron auge en los años de la República y volvía a poner el acento en el heroísmo abnegado de madres y esposas, en la importancia de su silenciosa y oscura labor como pilares del hogar cristiano" ("The post-war rhetoric applied to discrediting the connotations of feminism that took boom in the years of the Republic and once again emphasized the selfless heroism of mothers and wives, in the importance of their silent and dark work as pillars of the Christian home") (Martín Gaite, 2000, p. 82). C. does not follow the pattern of the devoted wife, her career is to be a writer. She is an active writer who also despises memory books for being boring and not representing new products (Santana, 2011, p. 103). Through her desire to produce a different book, she seeks to show that women are able to achieve it. In addition, it is shown that the production of her book has been based on the use she has given to a man. This man has been submissively listening, asking, and respecting $C$. In the space of the dream, the social roles of gender have been inverted.

With all that explained, $C$. projects Alejandro as a male to be able to impose herself as a woman. It was necessary to show in her book that a woman could use the figure of a man as an assistant. Also, in the postwar Spanish period, what she was doing was meaningful because it stripped the image of the superior man before a woman. Therefore, we must disagree with what García concludes by mentioning, "... (and perhaps Martín Gite) needs the involvement of the male, albeit an imaginary one, in order to feel complete as a woman" (33). The narrator did not need to feel complete, before the dream, she needed to recover her identity and overcome her fears. She needed an interlocutor and took advantage of a masculine figure. In this way, the interlocutor fulfilled different duties and did them for her. Furthermore, if she needed the man to feel complete, why did she end her dream by making him disappear? or, why did Martín Gaite allow the man to disappear? On the contrary, C. had been able to rebuild herself as a woman because she was able to manipulate the figure of a man in times when feminism was suppressed. After the dream, C., or the author Martín Gaite, ends up rejecting the imposed idea that women without men cannot continue with their lives. The protagonist did not necessitate the male presence, either fictitious or real. 


\section{Conclusion}

In conclusion, the man in black has been the guide, the referent of the present, the being to whom C. gave her unconscious, and the mechanism for criticism. This study analyzed the representation and the agency of the man. He was a tool for a woman who needed to overcome her fears and rebuild her past. When overcoming all her fears and uncertainties, she was able to reconstruct herself into a new individual. The protagonist calls for being herself since she had been living in fear (Carbayo, 1998, p. 120). She was able to understand and connect her present with her past, thus, allowing her to self-reconstruct. It is concluded that the novel El cuarto de atrás, ingeniously weaves a feminist message for women who seek empowerment and recognition from society, more specifically the masculine gender. It is in this manner that this study sought to expose new thoughts on the portrayal of Alejandro.

Grant Support: The author received no financial support for this work

\section{References}

Buczek, O. (2009). La Búsqueda de Interlocutor en la Novelística de Carmen Martín Gaite (Entre Visillos, El Cuarto de Atrás, Nubosidad Variable). LSMLL, 33, 7-20. http://www.Ismll.umcs.lublin.pl/issues/33-2009/1 buczek. pdf.

Carbayo Abengózar, M. (1998). Buscando un Lugar Entre Mujeres: Buceo en la España de Carmen Martín Gaite. Madrid: Universidad de Málaga.

Freud, S. (1963). The Unconscious. In P. Rieff (Ed.), General Psychological Theory: Papers on Metapsychology. New York, NY: Macmillan Publishing Company.

García, A. M. (2000). Silence in the Novels of Carmen Martín Gaite. New York, NY: Lang Publishing.

Guerrero Solier, E. (1992). El Interlocutor en la Obra de Carmen Martín Gaite. Analecta Malacitana, 15, 319-331. http://www.anmal.uma.es/numero2/Solier.htm.

Herzberger, D. K. (1991). Narrating the past: History and the Novel of Memory in Postwar Spain. PMLA, 106 (1), 34-45. http://www.jstor.org/stable/462821.

Martín Gaite, C. (2003). El Cuarto de Atrás. Barcelona: Ediciones Destino. (2000). La Búsqueda de Interlocutor. La Búsqueda de Interlocutor (pp. 23-32). Barcelona: Anagrama. Ricoeur, J. P. G. (2000). El Recuerdo y la Imagen. La Memoria, La Historia, El Olvido (pp. 66-79). Buenos Aires: Fondo de Cultura Económica de Argentina.

Santana, M. (2011). De el Cuarto de Atrás de Carmen Martín Gaite a La Meitat de L'ànima de Carme Riera: Notas Sobre la Memoria Histórica en la Novela Contemporánea. Tejuelo, (10), 97-110. http://dehesa.unex.es/ bitstream/handle/10662/4658/1988-8430_10_97.pdf?sequence=1. 
